Ann. Génét. Sél. anim., I978, 10 (4), 5I7-523.

\title{
A badger-face-like color variant in Texel and in Dutch sheep in the Netherlands
}

\author{
P HOOGSCHAGEN $(*)$, S. ADALSTEINSSON $(* *)$ and J. J. LAUVERGNE $\left({ }^{* * *}\right)$ \\ (*) Ministry of Agriculture and Fisheries \\ Department for Animal Husbandry and Dairying \\ Bezuidenhoutseweg 73 The Hague The Netherlands \\ (**) Agricultural Research Institute, \\ Keldnaholt, Ito Reykjavik, Island \\ $\left(^{* * *}\right)$ Département de Génétique animale,

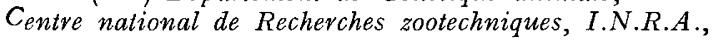 \\ 78350 Jouy-en-Josas, France
}

\begin{abstract}
Summary
A new color variant has been found in Dutch and in Texel sheep from the Netherlands. Phenotypically this variant localy called "blue " is very close from the well known badger-face pattern: black belly, legs and bars on head but one can see in the "blue "Dutch sheep a tendency of greying of the dark zones, specially with age. As for the other "badger-face " patterns which have been genetically studied, the breeding results are in favour of an allele at the Agout $i$ locus. Many cases of badger-faces have been described in breeds which often are not closely related, at least recently but, even, one hesitates to consider each case and specially Dutch Texel on as deriving from an original mutation each time.
\end{abstract}

In I 976 one of us (P. H.) was called to see a new color variant in a flock of Dutch $(\mathbf{1})$ sheep in Friesland. This color variant was named "blauw" (blue) by the owner.

A first note has been given (Hoogschagen, I978). The present article brings some additional data and interpretations.

\section{Material and methods}

All the data concerning appraisal of the first case including breeding results were collected in the first flock and the reproducing animal from that flock which were dispersed by sale have been followed in their new flocks.

(1) We have chosen the name Dutch to the actual common Texel-like sheep of the Netherlands which is not registered in the Texel Flock-book (LaUvergne and Hoogschagen, 1978). 
Enquiry was made among the sheep world in the Netherlands in order to find out another cases through an article in "Het Schaap " (issue of august and october I978).

\section{Results}

\section{A. - Cases history}

The first detected klue lamb a male was born in Ing. A. OosterbaAn's flock, Synaede State Tzummarum, Friesland, more than ten years ago, among triplets from a mating between white Dutch parents. A few months after the birth of this blue lamb Mr OOSTERBAAN heard that a similar lamb had been born nearly contemporarily in another flock. He was able to purchase the animal and started to create a blue line.

Furthermore we learn that a blue lamb was born at the IVO (Institute for Research in Animal Husbandry at Zeist) some years ago (M. VISScher, personal communication).

After the call in "Het Schaap " a few sheep breeders responded that, in their flocks too, blue animals had been born in 1978 or earlier.

The details concerning all the cases up to now detected in the Netherlands have been summarized in table $I$.

\section{TABLEAU I}

List of spontaneously born "blue " lambs in the Netherlands (I968-1978): first known cases and cases detected by the enquiry in "Het Schaap " (1978)

Liste des naissances spontanées d'agneaux "bleus" aux Pays-Bas (1968-1978): premiers cas connus et cas détectés par l'enquête du journal "Het Shaap " (I987)

\begin{tabular}{|c|c|c|c|c|c|c|c|c|}
\hline \multicolumn{3}{|c|}{ Father } & \multicolumn{2}{|c|}{ Mother } & \multirow{2}{*}{$\begin{array}{l}\text { Date } \\
\text { of } \\
\text { Birth }\end{array}$} & \multirow{2}{*}{$\begin{array}{c}\text { Num- } \\
\text { ber }\end{array}$} & \multirow{2}{*}{ Sex } & \multirow{2}{*}{ Flock } \\
\hline Name & Breed & Color & Breed & Color & & & & \\
\hline $\begin{array}{l}\text { Berend } \\
\text { Berend } \\
\text { Berend } \\
\text { Berend } \\
\text { Berend }\end{array}$ & $\begin{array}{c}\text { Dutch } \\
\text { Dutch } \\
\text { Texel( }\left(^{(}\right) \\
\text {Texel } \\
\text { Texel } \\
\text { Texel } \\
\text { Texel } \\
\text { Texel } \\
\text { Texel }\left(^{2}\right) \\
\text { or Dutch } \\
\text { Texel }\left({ }^{2}\right) \\
\text { or Dutch }\end{array}$ & $\begin{array}{l}\text { White } \\
\text { White } \\
\text { White } \\
\text { White } \\
\text { White } \\
\text { White } \\
\text { White } \\
\text { White } \\
\text { White } \\
\text { White }\end{array}$ & $\begin{array}{l}\text { Dutch } \\
\text { Dutch } \\
\text { Finn. } \\
\text { Texel } \\
\text { Texel } \\
\text { Texel } \\
\text { Dutch } \\
\text { Dutch } \\
\text { Dutch }\end{array}$ & $\begin{array}{c}\text { White } \\
\text { White } \\
\text { ? } \\
\text { White } \\
\text { White } \\
\text { White } \\
\text { White } \\
\text { White } \\
\text { Black } \\
\text { Black }\end{array}$ & $\begin{array}{l} \pm 68 \\
\pm 69 \\
\pm 75 \\
1977 \\
1978 \\
1978 \\
1978 \\
1978 \\
1978 \\
1978\end{array}$ & $\begin{array}{l}\text { I } \\
\text { I } \\
\text { I } \\
\text { I } \\
\text { I } \\
\text { I } \\
\text { I } \\
\text { I } \\
\text { I }\end{array}$ & $\begin{array}{c}\mathrm{M} \\
\mathrm{F} \\
? \\
\mathrm{~F} \\
\mathrm{M} \\
\mathrm{F} \\
\mathrm{F} \\
\mathrm{F} \\
\mathrm{M} \\
\mathrm{F}\end{array}$ & $\begin{array}{l}\text { OOSTERBAAN (Fr.) } \\
\text { UNKNOWN. } \\
\text { IVO, ZEIST (U.) } \\
\text { HENSTRA and } \\
\text { BRUINSMA } \\
\text { TIJNJE (Fr.) }\end{array}$ \\
\hline
\end{tabular}

(1) The cross is perharps Finnish $\times$ Texel unstead of Texel $\times$ Finnish.

(2) Two rams were at the flock. 


\section{B. - Description}

At kirth the belly of the blue animal is rather dark, the dark colour extending backwards to the innerside of the hind-legs, up around the anus and the thighs. The dark colour extends forwards along the brisket to the inner side of
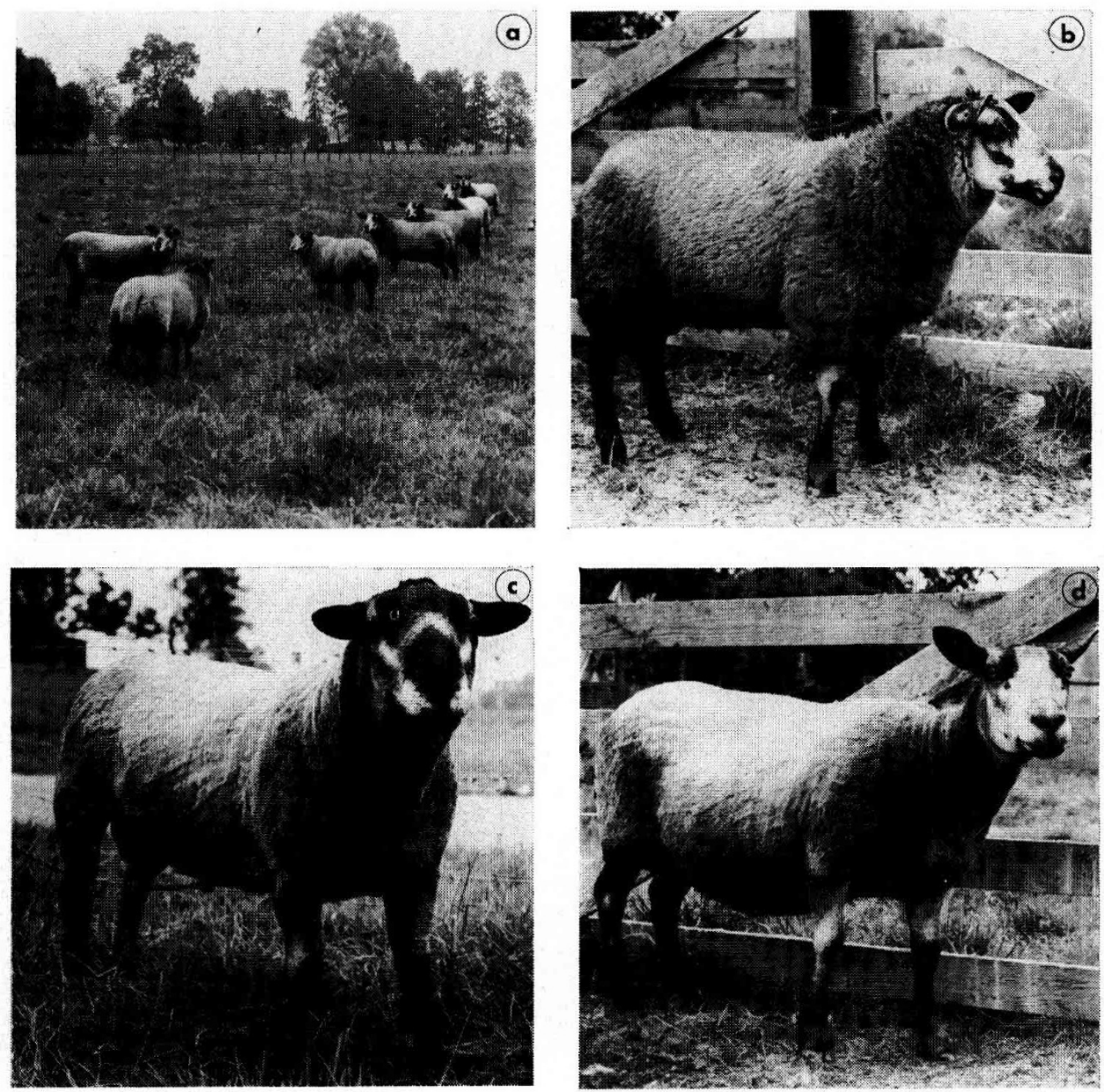

FIG. I. - "Blue " sheep at Mr VAN LAAR's farm, Woudenberg (Utrecht).

a) The flock in the meadow : sheared "blue " ewes and non sheared 4 months blue lambs.

b) Non sheared 4 months "blue " lamb.

c) One-and-a-half year old just sheared "blue " ram, note the black mask on nose and the greying.

d) Adult just sheared blue " ewe ", note the greying on shoulders, there is no black mask.

Moutons bleus de l'élevage VAN LAAR, Woudenberg (Utıecht).

a) Le troupeau au paturage : brebis "bleues " tondues et agneaux de 4 mois non tondus.

b) Agneau bleu de 4 mois non tondu.

c) Bélier bleu tondu d'un an et demi, noter le masque noir sur le nez et le grisonnement des épaules.

d) Brebis bleue adulte fraîchement tondue, le masque noir du nez est absent, on note le grisonnement au niveau des épaules. 
the forelegs up along the underside and the side of the neck and also on the shoulders.

A dark line widens from the neck on to the underjaw. The inside of the ears is dark and there is a dark bar above each eye and another one less wide under each eye plus usually a dark mask on the nose.

The pattern is highly symmetrical and the parts of the body which are not dark look white.

Some of the dark areas look black at birth and other are already grey by intermixing black and white fibers. With ageing the greying usually increases.
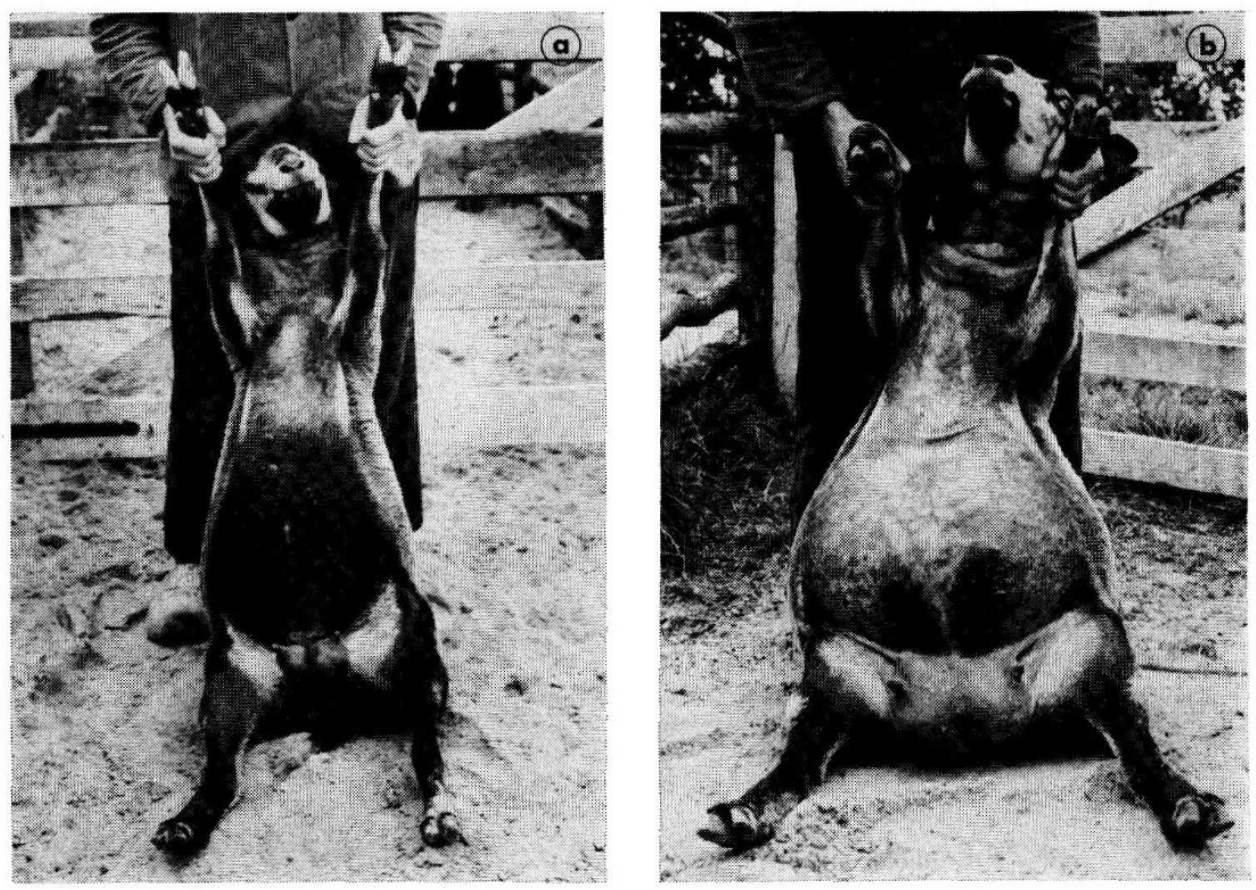

FIG. 2, $a$ and $b$. - Ventral view of ewes with different extents of belly pigmentation.

Vues ventrales de brebis avec différentes extensions de la pigmentation ventrale.

This greying giving some blue glints, is responsikle for the name of " blue " sheep given by the breeders.

The extent of coloration and its variation is illustrated in fig. I and 2.

\section{C. -.. Breeding results}

The ancestry of spontaneously born blue lambs is given in table $\mathbf{I}$. The results of controlled crossings made by $\mathrm{Mr}$ OOSTERBAAN and by the breeders who in 1977 bought the bluish breeding animal from his flock are given in table 2 .

One knows also that at HENSTRA and BRUINSmA's flock the maternal grandfather in 4 cases was Cyrus which has a common ancestor with the father Berend. 
TABLEAU 2

Breeding results with "blue " animals: flocks OOSTERBAAN, VAN LAAR and BOELSTRA Résultats de croisements avec des animaux "bleus "dans les troupeaux OSTERBAAN, VAN LAAR et BOELSTRA

\begin{tabular}{|c|c|c|c|c|c|}
\hline Flock and year & & & Father & Mother & Progeny \\
\hline $\begin{array}{llll}\text { VAN LAAR's }\left({ }^{1}\right) & (1978) & \cdot & \text {. } \\
\text { BOELSTRA's }\left({ }^{2}\right) & (1978) & \text { (197. } & \text {. }\end{array}$ & $\begin{array}{l}. \\
.\end{array}$ & 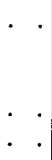 & $\begin{array}{l}\text { Blue } \\
\text { Blue } \\
\text { Blue } \\
\text { Blue }\end{array}$ & $\begin{array}{l}\text { Several } \\
\text { white ewes } \\
\text { Blue } \\
\text { Blue } \\
\text { Blue }\end{array}$ & $\begin{array}{l}\text { Mainly white lambs but also } \\
\text { some blue } \\
\text { Only blue lambs, at least ro births } \\
6 \text { blue } \\
9 \text { blue }\end{array}$ \\
\hline
\end{tabular}

(1) G. VAN IAAR, Woudenberg (Utrechnt).

(2) S. S. Boelstra, St. Anna Jacobi Parochie (Friesland).

\section{Discussion}

The data from tables I and 2 show that the blue variant behaves as a recessive towards the common white coloration in Texel and Dutch sheep.

One can think that the gene inducing the blue is allelic with the $A^{\text {wh }}$ gene in Agouti locus which, according LAUVERGNE and HoogsCHAGEN (I978) is responsible for the white colour of these breeds.

This interpretation is in accordance with the phenotypic observations of the blue variant which is very close from the badger-face pattern, a pattern first genetically described by HELLER (I I I ) in the sheep and which precisely has been demonstrated to be given by an allele in Agouti locus (Brooker and DolLING, ig69, ADALSTEINSSON, I970).

There is an alternative hypothesis: blue being given by recessive allele at another locus which were epistatic on Agouti genotypes. A definite proof of the first hypothesis were by crossing white animals heterozygous for the blue factor to homozygous recessive black animals $a a$ and obtaining some "blue ". Some "blue " lambs have been born in white $\times$ black crossings (cf. table $\mathrm{I}$ ) but one is not absolutely sure the black ewes were black by $a a$ or by $E^{d} E^{+}$(dominant black).

Now, if one consider the badger-face pattern, one can see it is present in many breeds such as Rambouillet (U.S.A.) (HELLER, I9I7) Spaelsau from Norway (WRIEDT, I924), Black Welsh Mountains in Great Britain (ROBERTS, I924, ROBERTS and White, I930), Castilian (SANChez-Belda, I95I), Spanish Merino (SANChezBELDA, I952) in Spain, Australian merinos (BRookER and Doli.ING, I969), Icelandic sheep (ADALSTEINSSON, I970), Corsican sheep (LAUVERGNE and ADALSTEINSSON, I976) as well as in Barbados sheep from the Caribbean (MAUlE, I977; Mason, I978) and some sheep from the Cameroon (MASON, I977). This list is probably incomplete as several archaic sheep breeds in Africa in the Middle East and in Central Asia have not yet been seriously checked for colour patterns.

Of course it is impossible to assert that all the badger-face patterns are given by the same gene originating from a given mutation but there are certainly not 
as many badger-face mutations as there are breeds wearing this colour variant even if several independant mutations with a close expressivity are possible.

Comparing badger-face variants in Corsica and Iceland LAUUVERGNE and Adalsteinsson (I976) have implicitly admitted it was the same gene: $A^{b}$. For the "blue " variant in the Texel and Dutch sheep Hoogschagen (I978) brought another allele $A^{b l}$. This may be supported by the greying of "blue " Dutch, a usually absent trait in badger-face from other breeds but detailed studies of badger-face expressivity are lacking in most of the cases and the existence of modificator genes may be posponned to explain this greying in the white breeds of the Netherlands.

$$
\text { Reçu pour publication en février } 1979 .
$$

\section{Acknowledgments}

Th1s study was only made possible with the cooperation of breeders of "blue " sheep (1.e. Ing. A. Oosterbann G., Van LAAR, S. S. BOELSTRA) and with the help of those who answerd to the enquiry in "Het Schaap".

\section{Résumé}

Un variant coloré semblable à " blaireau " dans les races ovines Texel et Dutch aux Pays-Bas

Un nouveau variant coloré a été trouvé en races Dutch et Texel aux Pays-Bas. Localement apperé "bleu " ce variant est phénotypiquement très proche du patron "blaireau " bien connu chez le mouton : ventre noir, pattes noires, listes noires en tête mais, chez le mouton "bleu " Dutch ou Texel on note une tendance au grisonnement des zones noires, spécialement avec l'âge. Comme pour les autres patrons "blaireau " qui ont été étudiés génétiquement les résultats de croisement ont montré que le gène responsable était un allèle en Agouti. Beaucoup de patrons "blaireau ont été signalés dans des races de moutons parfois assez éloignées génétiquement depuis longtemps. On hésite cependant à considérer tous ces cas, en particulier celui du mouton "bleu " des Pays-Bas, comme ayant des origines mutationnelles distinctes.

\section{References}

ADALSTEINSSON S., I970. Colour in heritance in Icelandic sheep and relation between colour, fertility and fertilization. J. Agric. res. Icel., 2, 3-I35.

BroOKER M. G., Dolling C. H. S., I969. Pigmentation of sheep. II The inheritance of colour patterns in black merinos. Austr. J. Agric. Res., 20, 387-394.

HELLER L. L., I9I5. Reversion in sheep. J. Heved., 6, 480.

Hoogschagen P., 1978. Blauwe schapen in Nederland (in dutch): Zeldzaam Huisdier, 3 (2), 6-9.

LAUVergne J. J., Adalsteinsson S., i976. Gènes pour la couleur de la toison de la brebis Corse. Ann. Génét. Sél. anim., 8, I53-172.

I.AUVERgne J. J., Hoogschagen P., r978. Genetic formulas for the colours in the Texel, the Dutch and the Zwartbles sheep in the Netherlands. Ann. Génét. Sél. anim., 10,

Mason I. L., I977. Tropical sheep in Southern Cameroon, 4 p.

MaSon I. L., I978. Report on a visit during 4 january-I4 february 1978 to Barbados, Ste Croix, Dominican Republic, Haïti, Jamaica, Cuba, Mexico, U.S.A.. F.A.O.-U.N.E.P. Project, conservation of Animal Genetic Resources : Prolific Tropical Sheep. F.A.O., Rome. 
MAUlE J. P., I977. Barbados blackbelly sheep. World anim. Rev., 24, I4-23.

ROBERTS J. A. F., I924. Colour in heritance in sheep. I Black colour and badgerface pattern in Welsh Mountains sheep. J. Genet., 14, 367-374.

RobERTS J. A. F., WhITE R. G., I930. Colour inheritance in sheep. IV. White colour, recessive black colour, recessive brown colour, badger face pattern and rbf pattern. J. Genet., 22, 165-180.

SANCHEZ BELDA A., I95ז. Identificacion del "badger-face" entre los ovinos españoles. An. Fac. Veter. Madrid, 3, 203-308.

SANCHEZ Belda A., I952. Nuevas aportaciones al conocimiento de la pigmentation de los ovinos. Zootecnia, 1 (4), 2 I-27.

WRIEDT C., I924. The Gromet pattern in sheep. J. Hered., 15, 125. 